\title{
EXPOSITION
}

\section{Legislation in Ukraine to Manage the Radiological Consequences of the Chernobyl Accident}

\author{
Oleg NASVIT ${ }^{* * * 1}$ and Tetsuji IMANAKA ${ }^{* * * 2}$
}

(Received April 6, 1998)

KEY WORDS: Chernobyl accident, Ukraine, radioactive pollution, radiation safety regulations, state registry

\section{PRINCIPAL LAWS TO MANAGE THE CONSEQUENCES OF THE CHERNOBYL ACCIDENT}

\section{Basic concept}

The description of the Ukrainian system of laws concerning the problem of the Chernobyl catastrophe should begin with a quote from a document of general character, "Concept of population residence on the territories of Ukrainian SSR with increased levels of radioactive contamination as a result of the Chernobyl accident." This document, small in volume, was adopted by the Supreme Soviet of Ukrainian SSR on February 27, 1991. It was planned that this Concept would provide for the decrease of negative influences on public health from the Chernobyl accident.

The main principle of the Concept is as follows: for the critical group of population-children born in 1986 - the effective exposure dose due to the Chernobyl accident should not exceed $1 \mathrm{mSv}$ per year or $70 \mathrm{mSv}$ for life in any specific environment.

* オレグ・ナスビット, **今中哲二

${ }^{* 1}$ Institute of Hydrobiology, National Academy of Sciences of Ukraine; 12 pr. Geroev Stalingrada, Kyiv 254210, Ukraine.

*2 Research Reactor Institute, Kyoto University; Kumatoricho, Sennnan-gun, Osaka 590-0494, Japan. 京都大学原子炉実験所; 大阪府泉南郡熊取町 (广 5900494)
The Concept states that "the situation on the contaminated territories demonstrates low effectiveness of countermeasures aimed at eliminating harmful effects of radiation on the health of people," and, therefore, "evacuation of people from these territories is of particular importance." In the Concept, the soil density of radioactive contamination (deposition) is considered to be a temporary (until individual effective dose is identified) criterion for making a decision on resettlement. As it is impossible to resettle a great number of people simultaneously, the Concept presumes "a principle of differentiated, step-by-step resettlement" as follows:

- Stage I-obligatory resettlement - is practiced on the territories with cesium deposition above $555 \mathrm{kBq} / \mathrm{m}^{2}$, above $111 \mathrm{kBq} / \mathrm{m}^{2}$ for strontium deposition, or above $3.7 \mathrm{kBq} / \mathrm{m}^{2}$ for plutonium, where residence of people under those conditions can cause an additional effective exposure dose exceeding $5 \mathrm{mSv}$ per year, which is dangerous for health

- Stage II-guaranteed voluntary resettlementis practiced on the territories with cesium deposition from 185 to $555 \mathrm{kBq} / \mathrm{m}^{2}$, with strontium from 5.55 to $111 \mathrm{kBq} / \mathrm{m}^{2}$, or with plutonium from 0.37 to $3.7 \mathrm{kBq} / \mathrm{m}^{2}$, where residence of the population under those conditions can cause an additional effective exposure dose exceeding 1 
$\mathrm{mSv}$ per year, which is dangerous for health.

Some additional criteria have also been established to make decisions on resettlement. These criteria relate to the possibility of growing radiologically "clean" agricultural products.

A very important aspect of the Concept is the statement that "after the Chernobyl accident the conditions for the combined effect of radioactive exposure and factors of non-radioactive origin (synergism) arose. This greatly increases negative influences of low radiation doses on the health status of the population, especially that of children. In this situation the extent of synergism is an additional criteria for making decisions on introducing any counter-radiation measures."

On the territories with a contamination density of cesium isotope below $185 \mathrm{kBq} / \mathrm{m}^{2}$, strontium below $5.55 \mathrm{kBq} / \mathrm{m}^{2}$, or plutonium below $0.37 \mathrm{kBq} /$ $\mathrm{m}^{2}$, residence is allowed only with enhanced control and on the condition that the additional effective dose from the Chernobyl accident does not exceed $1 \mathrm{mSv}$ per year. If this condition is not met, the population should be given the option to resettle to radioecologically "clean" areas.

Implementation of the principles of the Concept should be based on the following two Ukrainian laws: "On the legal status of the territory subjected to radioactive contamination as a result of the Chernobyl catastrophe" and "On the status and social protection of the citizens who suffered as a result of the Chernobyl catastrophe."

\section{Basic laws aimed at liquidating the accident consequences}

The Ukrainian Law, "On the legal status of the territory subjected to radioactive contamination as a result of the Chernobyl catastrophe" was adopted by the Supreme Soviet of Ukrainian SSR on February 27, 1991, and has been effective since July 1, 1991. Changes and additions have been introduced by laws of Ukraine (by Verkhovna Rada, i.e. Ukrainian parliament) on 17.12.91, 01.07.92, 28.04.95, 22.12.95, 17.12.96, 04.04.97; and by a decree of the Cabinet of Ministers of Ukraine dated 26.12 .92

This law is aimed at regulating "classification of the territories into zones in accordance to the levels of contamination; the utilization and security regime of the territories; living and work conditions of the population; production, research and other types of activities in these zones."

This law consists of 6 chapters:

I. General.

II. Legal status of exclusion zone and zone of obligatory resettlement.

III. Legal status of guaranteed voluntary resettlement zone.

IV. Legal status of the zone of enhanced radioecological control.

V. Control of the legal status of the zones subjected to radioactive contamination after the Chernobyl catastrophe.

VI. Liability for the violation of the legal status in the zones subjected to radioactive contamination after the Chernobyl catastrophe.

Article 1 of the law gives the definition of the territories subjected to radioactive contamination as a result of the Chernobyl catastrophe-these are the territories where "the persistent contamination of the environment with radioactive substances exceeding the level before the accident ... can

Table 1 Criteria for identifying the zones of radioactive contamination

\begin{tabular}{|c|c|c|c|c|c|}
\hline \multirow{2}{*}{ No. } & \multirow{2}{*}{ Zones } & \multicolumn{3}{|c|}{ Deposition, $\mathrm{kBq} / \mathrm{m}^{2}\left(\mathrm{Ci} / \mathrm{km}^{2}\right)$} & \multirow{2}{*}{$\begin{array}{c}\text { Calculated } \\
\text { dose, } \mathrm{mSv} \cdot \mathrm{y}^{-1}\end{array}$} \\
\hline & & ${ }^{137} \mathrm{Cs}$ & ${ }^{90} \mathrm{Sr}$ & $\mathrm{Pu}$ & \\
\hline 1 & Exclusion & n.d. & n.d. & n.d. & n.d. \\
\hline 2 & Obligatory resettlement & $>555(15)$ & $>111(3)$ & $>3.7(0.1)$ & Can exceed 5 \\
\hline 3 & $\begin{array}{l}\text { Guaranteed voluntary } \\
\text { resettlement }\end{array}$ & $\begin{array}{l}185-555 \\
(5-15)\end{array}$ & $\begin{array}{l}5.55-111 \\
(0.15-3)\end{array}$ & $\begin{array}{c}0.37-3.7 \\
(0.01-0.1)\end{array}$ & Can exceed 1 \\
\hline 4 & $\begin{array}{l}\text { Enhanced radioecological } \\
\text { control (monitoring) }\end{array}$ & $\begin{array}{c}37-185 \\
(1-5)\end{array}$ & $\begin{array}{c}0.74-5.55 \\
(0.02-0.15)\end{array}$ & $\begin{array}{c}0.185-0.37 \\
(0.005-0.01)\end{array}$ & Exceeds 0.5 \\
\hline
\end{tabular}

n.d.: not determined. Exclusion zone-The territory from which the people were evacuated in 1986. 
cause population irradiation above $1 \mathrm{mSv} /$ year ..." On these territories special measures should be introduced in order to provide radiation protection and to allow for the normal life activity of the population.

Article 2 defines the categories of the zones of contaminated territories. Table 1 presents the summary of criteria for identification of zones of radioactive contamination as a result of the Chernobyl catastrophe. As easily seen in Table $\mathbf{1}$, there is a contradiction between Articles 1 and 2. In Article 1 , the contaminated territory is defined as the area where additional irradiation due to the accident can be over $1 \mathrm{mSv}$ per year. Then in Article 2, when the contaminated territories are classified, the zone of enhanced radioecological control (monitoring), defined as Zone-4 in Table 1, includes the area where the additional irradiation dose is less than $1 \mathrm{mSv}$, e.g. from $0.5 \mathrm{mSv}$ or more.

The criteria of the zone identification are set by the National Commission of Radiation Protection of Ukrainian Population (NCRPU). The zone borders are identified by the Cabinet of Ministers of Ukraine proceeding from the expert conclusions of NCRPU, the National Academy of Sciences of Ukraine (NASU), the Ministry of Health, the Ministry of Chernobyl Affairs (MinChernobyl), the Ministry of Agriculture, the Ministry of Ecological Safety, the State Hydrometeorological Committee, and by the representation of the Regional deputy councils. According to the additions to the law adopted by Verkhovna Rada (Ukrainian parliament) in 1996, no changes could be made to the zone borders without approval from Verkhovna Rada.

Article 7 of the law in its initial edition provided tax exemption for enterprises, organizations, collective and state farms located in the zones of voluntary guaranteed resettlement and enhanced radioecological control, except payments to local budgets. At the end of 1992, the exemption from tax on profits was cancelled, and from January 1996, the exemption from taxes, customs and excise duties on imported excisable goods was cancelled.

The next article is cited here, as it is of special interest for any involved in scientific research con- cerning Chernobyl:

"Article 11. Ownership of the results of scientific research connected with the Chernobyl catastrophe. All scientific information and results of research obtained in the zones of radioactive contamination are the property of Ukraine and can be used only with the permission of the Cabinet of Ministers of Ukraine."

The law prescribes limitations on types of economic activities in the contaminated zones, aiming to decrease radiological and other toxic effects on the people living and working there, as well as at preventing transport of radionuclides outside the borders of the zones.

The article on the measures to reduce disease risk is very important from the point of view of population protection. In accordance with this article, the state has to guarantee:

- annual medical checks of the population and early prevention of diseases;

- supply of the necessary amount of medicines, potable water, clean foodstuffs to the population;

- provision of gas supply for the settlements, construction of concrete-covered roads, etc.

Article 21 of the law identifies responsibilities among the ministries and departments concerning radiation monitoring and provides the idea for the structure of the monitoring and location of the data. Table 2 are summarizes the contents of Article 21.

The law of Ukraine, "On the status and social protection of the citizens who suffered as a result of the Chernobyl catastrophe" was adopted by the Supreme Soviet of Ukrainian SSR on February 28, 1991, and has been effective since July 1, 1991. Changes and additions were introduced by laws of Ukraine (through Verkhovna Rada) on 19.12.91, 01.07.92, 05.05.93, 17.06.93, 06.04.95, 22.12.95, 22. 03.96, 06.06.96, 11.12.96, 27.06.97; and by decrees of the Cabinet of Ministers of Ukraine on 26.12.92, 26.03.93 and 30.04.93.

"The Law is aimed at protection of the citizens who suffered as a result of the Chernobyl catastrophe and at solving problems of a medical and social nature which arose as a result of radioactive contamination of the territories" (Article 
Table 2 Division of responsibilities among Ministries and Departments concerning radiation monitoring.

\begin{tabular}{|c|c|}
\hline Type of activity and control & Responsible Ministries \\
\hline $\begin{array}{l}\text { Prognostic estimates of the total human irradiation dose and } \\
\text { control of the radiation safety standards }\end{array}$ & -Ministry of Health \\
\hline $\begin{array}{l}\text { General assessment of radiological situation on the territories } \\
\text { of the zones, radioecological monitoring, methodical supervi- } \\
\text { sion and coordination of works on identifying the } \\
\text { radiological situation }\end{array}$ & -Ministry of Chernobyl Affairs \\
\hline \multicolumn{2}{|l|}{ Control of radioactive contamination levels of: } \\
\hline -farmlands & - Ministry of Food and Agriculture \\
\hline —water resources & -State Water Resources Committee. \\
\hline - subsurface waters and minerals & -State Geology Committee \\
\hline - atmosphere on the territory of contaminated settlements & - State Hydrometeorological Committee \\
\hline - agricultural products and foodstuffs & -Ministry of Food and Agriculture \\
\hline —vehicles and their parts & $\begin{array}{l}\text { - Ministries and committees on transportation } \\
\text { means and Ministry of Internal Affairs } \\
\text { - State Sanitary Control }\end{array}$ \\
\hline $\begin{array}{l}\text { - household belongings, tools and construction materials } \\
\text { during the transportation outside contaminated areas dur- } \\
\text { ing evacuation }\end{array}$ & -Civil Defense \\
\hline -domestic animals during the evacuation & - State Veterinary Control \\
\hline $\begin{array}{l}\text { Control of reliability and objectivity of the data of radiation } \\
\text { control services }\end{array}$ & -State Sanitary Control \\
\hline Methodology of radiation control services & - State Committee of Standards \\
\hline Radiation control of products & -enterprises, organizations-manufacturers \\
\hline
\end{tabular}

1).

The law consists of the following 10 chapters:

I. General.

II. Status of persons who suffered as a result of the Chernobyl catastrophe.

III. Unified system of registration and medical care for the persons who suffered as a result of the Chernobyl catastrophe.

IV. Social protection of the citizens affected by the Chernobyl catastrophe, general compensation and benefits.

V. Protection of the children who suffered as a result of the Chernobyl catastrophe.

VI. Protection of the population affected by the Chernobyl catastrophe.

VII. Specifics of labor regulation for citizens who work on the territories with radioactive contamination.

VIII. Pensions and compensation for persons related to categories $1,2,3,4$.

IX. Public associations of the persons who suffered as a result of the Chernobyl catastrophe.

X. Final statement.

Article 2 provides the definition of the zones of radioactive contamination (in fact, it is the same as Article 2 of the previous law), and in Article 3 it is stated that "considering the radiation factor, the condition for living and working without limitations is an additional irradiation dose which does not exceed $1 \mathrm{mSv}$ per year." Thus, the contradiction between Articles 1 and Article 2 of the previ- 
ous law can also be found in this law.

Further, the law sets limitations for entering the radioactively contaminated territories for permanent residence, and states the necessary and sufficient conditions for resettlement of the people. In particular, the right for self-resettlement (before the social conditions for resettlement are prepared by the authorities) is given to people whose individual effective dose exceeds $70 \mathrm{mSv}$ for the life period. In reality, however, this right is given only to those who received this dose by the present time because there is no method of dose prognosis confirmed by competent authorities. A very important, but also a very disputable statement is that "the population in the zone of obligatory resettlement is to be resettled without fail."

This law defines that the values of acceptable levels of radionuclides content in foodstuffs and agricultural products are approved and put into practice by the Ministry of Health of Ukraine

Table 3 Definition of categories of the people who suffered from the Chernobyl catastrophe.

\begin{tabular}{|c|c|}
\hline Category & Description \\
\hline I & $\begin{array}{l}\text { Invalids, belonging to liquidators and affected residents, for whom the causal relation between } \\
\text { their disability and the Chernobyl catastrophe has been proved; } \\
\text { Persons who got radiation syndrome as a result of the Chernobyl catastrophe. }\end{array}$ \\
\hline II & $\begin{array}{l}\text { Liquidators who worked in the exclusion zone: } \\
\text { - from the accident to July 1, 1986: independently of length of working days; } \\
\text { - from July 1, } 1986 \text { to December } 31,1986 \text { : not less than } 5 \text { days; } \\
\text {-in 1987: not less than } 14 \text { days; } \\
\text { Affected residents: } \\
\text { - evacuated from the exclusion zone in 1986; } \\
\text { - continuously lived in the zone of obligatory resettlement from the accident to the moment of } \\
\text { adoption of the decree on resettlement. }\end{array}$ \\
\hline III & $\begin{array}{l}\text { Liquidators who worked: } \\
\text {-in the exclusion zone from July } 1,1986 \text { to December } 31,1986 \text { : from } 1 \text { to } 5 \text { days; } \\
\text {-in the exclusion zone in 1987: from } 1 \text { to } 14 \text { days; } \\
\text {-in the exclusion zone in 1988-1990: not less than } 30 \text { days; } \\
\text { - on sanitary treatment of people and decontamination of equipment or on construction of these } \\
\text { stations; } \\
\text { Affected residents (not referred in category II), who: } \\
\text { - continuously lived on the territory of zones of obligatory resettlement and guaranteed voluntary } \\
\text { resettlement on the day of accident, or by January 1, 1993, provided that they spent not less than } \\
\text { two years in the zone of obligatory resettlement, or three years in the zone of guaranteed voluntary } \\
\text { resettlement, and were resettled from these territories; } \\
\text { - were continuously living, working, or studying in the zones of obligatory resettlement or } \\
\text { guaranteed voluntary resettlement, provided that by January } 1 \text {, 1993, they had spent not less than } \\
\text { two years in the zone of obligatory resettlement, or three years in the zone of guaranteed voluntary } \\
\text { resettlement. }\end{array}$ \\
\hline
\end{tabular}

IV Affected residents who were continuously living, working, or studying in the zone of enhanced radioecological control (monitoring), provided that by January 1, 1993, they had spent not less than 4 years in this zone. 
on approval of the National Commission on Radiological Protection of Ukraine.

The Cabinet of Ministers of Ukraine is responsible for the reliability, completeness and timeliness of the information on radioactive contamination levels of the environment and foodstuffs, as well as for the requirements and conditions of radiation safety.

According to this law, the people who suffered from the Chernobyl catastrophe include those who participated in the liquidation of its consequences and residents, including children, who were affected by irradiation as a result of the Chernobyl catastrophe. The law defines 4 categories of the people affected by the Chernobyl catastrophe (Table 3). The amount of all compensation and benefits depends on the category of the person and status of the territory of their residence and work.

The State should compensate for the following:

1) health damage or loss of working ability of the people caused by the Chernobyl catastrophe;

2) parent death of children if his/her death is caused by the Chernobyl catastrophe;

3) material loss of the people and their families caused by the Chernobyl catastrophe.

The State is responsible for providing medical examinations to the people affected by the Chernobyl catastrophe. Of great importance is the statement in the law that "the causal relation between the deterioration of health status, disease ... loss of ability to work of the people who suffered from the Chernobyl catastrophe and the Chernobyl catastrophe is identified (independently of whether the dosimetry results are available or not) unless the authorized medical institution confirms the absence of such relation."

Further, compensation and benefits are specified by this law for the citizens who suffered as a result of the Chernobyl catastrophe. The list of all the benefits and compensations occupies 11 pages. Benefits and compensation can be both of a onetime nature, e.g. free supply of dwellings and compensation for lost property (houses, vehicles, domestic animals and fruit plants), and of an on-going nature, e.g. free medicines, free treatment in sanatoriums, salary increases, additional pay- ment for enhanced food, increased pensions, free use of city transport, and earlier retirement age.

It is stated in this law that citizens who suffered as a result of the Chernobyl catastrophe have advantages in applying for jobs and in keeping their positions during staff reductions at enterprises and organizations. This creates conflict, as it causes the dissatisfaction and anger of more experienced and qualified workers. The law declares that the local councils should set aside $15 \%$ of all dwellings built annually to provide for the benefits envisaged by the law. This also creates a basis for conflict because despite the allocation of special funds, the queue of those waiting for housing is very long.

Rather strange is the statement in the law that "the salary of the workers at enterprises, organizations and institutions who work on the construction of the objects within the program of the liquidation of the Chernobyl accident consequences should be $20 \%$ above the standard rate."

The law also provides the definition of the children considered as affected by the Chernobyl catastrophe and identifies the following benefits and compensation for such children and their parents: total state insurance of the children before they reach school age; annual free treatment in sanatoriums and resorts for a period of up to 2 months; increase in salary for one of the parents; prolonged maternity leave for women who suffered as a result of the Chernobyl catastrophe up to 180 paid days, etc.

The expenses related to the implementation of this law are financed from the State budget. The Cabinet of Ministers of Ukraine is responsible for clarifying how to implement the law.

\section{LAWS AND REGULATIONS ON RADIATION PROTECTION}

\section{Laws and regulations on dose limits}

The basic document on radiation protection on the territory of the former USSR was the Standards of Radiation Safety SRS-76/87, which had been effective in Ukraine until the end of 1997. According to $S R S-76 / 87$, three categories of irradiated persons were identified:

- Category A: staff-persons directly working with sources of ionizing radiation (SIR) 
- Category B: certain parts of the populationpersons who are not working directly with SIR, but by their living conditions (this made an essential difference with the international standards !!!) or by the location of their work places may be affected by radioactive substances or other SIR.

- Category C: population-population of the country, region, etc.

For Categories $\mathrm{A}$ and $\mathrm{B}$, dose limits were identified to be $50 \mathrm{mSv}$ per year and $5 \mathrm{mSv}$ per year, respectively. For Category $\mathrm{C}$, however, a dose limit was not determined. There was only a requirement for implementing measures to restrict irradiation of the population. In the case of a radiation accident, "depending on the scale and character of an accident, the Ministry of Health could establish temporary dose limits and permissible levels for the population."

In 1997 the Ministry of Health of Ukraine adopted new Standards of Radiation Safety of Ukraine, SRSU-97, mainly based on international safety standards. ${ }^{1)}$ SRSU-97 has been put into practice from 1998.

The $S R S U-97$ document contains 4 categories of regulations:

- 1st category-regulations to control the practice with sources of ionizing radiation. They include dose limits and derived limits (acceptable levels and control levels).

- 2nd category-regulations to limit irradiation from medical sources. They include recommended levels.

- 3 rd category-regulations concerning doses under the condition of radiation accidents. They define intervention levels and action levels on the basis of dose values reduced by means of countermeasures.

- 4th category-regulations concerning doses from man-enhanced natural sources. They define intervention levels and action levels.

Dose limits of the 1st category regulations are presented in Table 4. SRSU-97 presents a different definition for Category B of irradiated persons from that of $S R S-76 / 87$ : "Category B: staff-persons who do not directly work with SIR, but by the location of their work places may be affected by radioactive substances or other SIR." Derived limits of the 1st category regulations include acceptable concentrations of radionuclides in the air of working zone (for categories A and B, personnel), acceptable concentrations of radionuclides in the air and drinking water (for category C, population). The values of these concentrations are calculated from dose limits taking into account reference conditions of irradiation from intake of each radionuclide.

In the case of radiation accidents, a series of countermeasures are supposed to be undertaken as of urgent- and long-term characters. In SRSU-97, two levels of criteria to implement countermeasures are presented based on predicted values of dose reduction by protective actions; "lowest level of justification" and "indisputable level of justification." Table 5 shows criteria to implement urgent countermeasures. In a case that values of dose reduction lie between two levels, the decision of protective actions will be made considering local

Table 4 New dose limits for total (internal and external) irradiation $\left(\mathrm{mSv} \cdot \mathrm{y}^{-1}\right)$.

\begin{tabular}{|c|c|c|c|}
\hline \multirow{2}{*}{ Dose limits } & \multicolumn{3}{|c|}{ Category of irradiated persons* } \\
\hline & A & $\mathrm{B}$ & $\mathrm{C}$ \\
\hline Effective dose & $20 * *$ & 2 & 1 \\
\hline \multicolumn{4}{|l|}{ Dose equivalent: } \\
\hline for crystalline lens & 150 & 15 & 15 \\
\hline for skin & 500 & 50 & 50 \\
\hline for hands and feet & 500 & 50 & - \\
\hline
\end{tabular}

Remark: ${ }^{*}$-see text. ${ }^{* *}$-on average for any 5 consecutive years, but not more than $50 \mathrm{mSv}$ for separate years. 
Table 5 Criteria to implement urgent countermeasures in the case of radiation accidents. (Values of lowest level of justification and indisputably justified level)

\begin{tabular}{|c|c|c|c|c|c|c|}
\hline \multirow{4}{*}{ Countermeasure } & \multicolumn{6}{|c|}{ Predicted dose reduction (prevention) for initial 2 weeks after the accident } \\
\hline & \multicolumn{3}{|c|}{ Lowest level of justification } & \multicolumn{3}{|c|}{ Indisputably justified level } \\
\hline & \multirow{2}{*}{$\frac{\mathrm{mSv}}{\text { Whole body }}$} & \multicolumn{2}{|c|}{ mGy } & \multirow{2}{*}{$\frac{\mathrm{mSv}}{\text { Whole body }}$} & \multicolumn{2}{|c|}{ mGy } \\
\hline & & Thyroid & Skin & & Thyroid & Skin \\
\hline Shielding & 5 & 50 & 100 & 50 & 300 & 500 \\
\hline Evacuation & 50 & 300 & 500 & 500 & 1,000 & 3,000 \\
\hline \multicolumn{7}{|l|}{ Iodine prophylactics; } \\
\hline children & - & 50 & - & - & 200 & - \\
\hline adults & - & 200 & - & - & 500 & - \\
\hline \multicolumn{7}{|c|}{ Restriction of staying outdoors; } \\
\hline children & 1 & 20 & 50 & 10 & 100 & 300 \\
\hline adults & 2 & 100 & 200 & 20 & 300 & 1,000 \\
\hline
\end{tabular}

and social conditions. SRSU-97 also defines criteria to implement resettlement, provisional resettlement and restriction on consumption of contaminated foodstuffs.

On January 14, 1998, when the present author was preparing this article, Verkhovna Rada of Ukraine adopted a new law of Ukraine, "On the protection of human from the influence of ionizing radiation." This law consists of 6 chapters and 24 articles. The chapters are:

I. General provisions

II. Basic dose limits of irradiation and intervention levels

III. Guaranteeing protection of human from the influence of ionizing radiation

IV. Compensation and indemnity of damages

V. International cooperation in the field of protection of human from the influence of ionizing radiation

\section{Final provisions}

The law begins from definitions of terms, which are somewhat different from those used in $S R S U$ 97. For example, the term "intervention level" in the law means the value of calculated committed dose the level of which causes a necessity for implementation of measures to protect human from ionizing radiation. In $S R S U-97$, however, the term "intervention level" means the dose value that can be reduced by means of protective actions. In accordance with the levels of dose reduction, implementations of protective actions are justified. So, although the figures in the law of intervention levels for shielding ( $5 \mathrm{mSv}$ per initial 10 days) and provisional evacuation of the people $(50 \mathrm{mSv}$ per 1 week) are similar to those in SRSU-97, the sense for radiation protection is absolutely different.

The law sets the basic dose limits for population ( $1 \mathrm{mSv}$ per year) and personnel $(20 \mathrm{mSv}$ per year, in certain circumstances up to $50 \mathrm{mSv}$ per year under the condition that the average dose for 5 year period does not exceed $20 \mathrm{mSv}$ per year). Underlined part in the law has a little less strict sense of regulation than the respective statement in $S R S U$ 97.

It is interesting to note that the law defines the value of compensation for exceeding the basic dose limits. The price is set about 10 US Dollars per 1 $\mathrm{mSv}$ over the limit at the present ratio, which concerns also cases of unjustified medical irradiation. This article will be putted into practice from January 1, 2000. From the text of the law, however, it is not clear whether it is applied to the Chernobyl problems or not.

\section{Laws and regulations on radioactivity levels of food, water and air}

According to $S R S-76 / 87$ of the former USSR, 
the permissible concentrations of radionuclides $\left(\mathrm{PC}_{\mathrm{B}}\right)$ in water and air are presented for the Category B. Its values were calculated with the assumption that if a person constantly inhales air with a radionuclide concentration equal to $\mathrm{PC}_{\mathrm{B}}$, or if a person constantly consumes water with a radionuclide concentration equal to $\mathrm{PC}_{\mathrm{B}}$, then the human irradiation dose will be $5 \mathrm{mSv}$ per year from each radionuclide by either route of intake (inhalation or ingestion). In certain situations where people receive irradiation from both pathways, derived permissible levels should be determined taking into account existing ratios of radionuclides in water and air.

After the Chernobyl accident in accordance with Soviet regulations, the Ministry of Health of the USSR defined in 1986, 1988 and 1991, tentative acceptable levels (TAL) for radionuclides in foodstuffs and potable water. ${ }^{2,3}$ In 1993, the National Commission on Radiological Protection of Ukraine issued the TAL-93 document. But since different Ukrainian Ministries did not come to an agreement about the figures in this document, it was not approved by the Ministry of Health. So, TAL-91 continued to be valid in Ukraine up to
1997. The main problem of TAL-93 was the groundlessness of its figures. Since 1994, however, local authorities of the contaminated regions brought into use local control levels (LCL) of radionuclides in food and agricultural products, mainly based on the TAL-93 figures, and also taking into account local conditions (Table 6). According to local laws, exceeding the LCL is subject to investigation and, if necessary, elaboration and implementation of countermeasures. In fact, only several percent of the products obtained from collective farms exceeded LCL values in 1995-1996. In the private sector of agriculture, however, this happens more often.

In 1997 the Ukrainian Ministry of Health approved acceptable levels for ${ }^{137} \mathrm{Cs}$ and ${ }^{90} \mathrm{Sr}$ in foodstuffs and potable water (AL-97). This document was put into practice from January 1, 1998. If a person of a critical group constantly consumes a reference ration composed of all products containing ${ }^{137} \mathrm{Cs}$ and ${ }^{90} \mathrm{Sr}$ at the levels presented in Table 7, he will receive $1 \mathrm{mSv}$ per year from ${ }^{137} \mathrm{Cs}$ and ${ }^{90} \mathrm{Sr}$, respectively. A product is considered to be acceptable for consumption if the sum of the ratios of actual concentrations of ${ }^{137} \mathrm{Cs}$ and ${ }^{90} \mathrm{Sr}$ at their

Table 6 Local control levels of ${ }^{137} \mathrm{Cs}$ concentration in food and agricultural products brought into use in different regions since $1994, \mathrm{~Bq} / \mathrm{l}, \mathrm{Bq} / \mathrm{kg}$.

\begin{tabular}{lccc}
\hline \multicolumn{1}{c}{ Foodstuff } & \multicolumn{2}{c}{ Regions } & Zhytomyr \\
\cline { 2 - 4 } & Kyiv & Volyn' & 4 \\
\hline 1. Drinking water & - & 4 & 74 \\
2. Milk & 74 & 74 & 75 \\
3. Different milk products & $74-148$ & 74 & - \\
4. Milk powder & - & 185 & 740 \\
5. Pork, beef, mutton, poultry & $74-148$ & 296 & - \\
6. Fish & $185-296$ & 296 & - \\
7. Potato & 60 & - & 185 \\
8. Root vegetables & 60 & - & 185 \\
9. Leafy vegetables, fruits, berries & 60 & - & 740 \\
10. Bread, grain products & - & 740 & 1,850 \\
11. Mushrooms fresh & - & 296 & - \\
12. dry & - & 37 & - \\
13. Eggs & 74 & - &
\end{tabular}


Table 7 Values of acceptable levels for ${ }^{137} \mathrm{Cs}$ and ${ }^{90} \mathrm{Sr}$ in foodstuff and potable water (AL-97), Bq/ kg, Bq/ $l$.

\begin{tabular}{lrr}
\hline \multicolumn{1}{c}{ Name of the product } & ${ }^{137} \mathrm{Cs}$ & 5 \\
\hline 1. Bread and bread products & 20 & 20 \\
2. Potato & 60 & 20 \\
3. Vegetables (root, leafy) & 40 & 10 \\
4. Fruits & 70 & 20 \\
5. Meat and meat products & 200 & 35 \\
6. Fish and fish products & 150 & 20 \\
7. Milk and milk products & 100 & 2 \\
8. Eggs (per piece) & 6 & $2 *)$ \\
9. Water & 2 & 60 \\
\hline 10. Milk concentrate & 300 & 100 \\
11. Milk powder & 500 & 50 \\
12. Fresh wild berries and mushrooms & 500 & 250 \\
13. Dried wild berries and mushrooms & 2,500 & 200 \\
14. Drug plants & 600 & 200 \\
15. Others & 600 & 5 \\
16. Special infants foodstuff & 40 & \\
\hline
\end{tabular}

*) Remark: 4 Bq/l until 01.01.1999

acceptable levels dose not exceed 1. Introduction of AL-97 provides the guarantee that the annual individual effective dose of internal irradiation due to consumption of food products does not exceed 1 $\mathrm{mSv}$ for any person.

\section{THE STATE REGISTRY OF CHERNOBYL SUFFERERS}

Right after the Chernobyl accident, the USSR Ministry of Health started a program to create the All-Union Distributed Register of irradiated persons. After the break up of the USSR, Ukraine inherited some uncoordinated parts of this register and had to develop its own system aimed to provide effective medical-social security for those suffering from the Chernobyl catastrophe. According to Article 16 (Organization of the united state registration of the persons who suffered from the Chernobyl catastrophe) of the law of Ukraine, "On the status and social protection of the citizens who suffered as a result of the Chernobyl catastrophe," the Ministry of Health was nominated to be responsible for implementation of this task. Formally the State Register was created, but due to a lack of coordination and shortage of funds, it did not provide a really united registration system. It is expected that this situation will change on approval of the "Regulations on organizing and functioning of the State Register of Ukraine of the persons who suffered from the consequences of the Chernobyl catastrophe" (approved by decree No. 571 of the Cabinet of Ministers of Ukraine on June 9, 1997).

The population size of principal groups in the State Register is shown in Table 8. ${ }^{4}$ In total, 474,095 persons had been registered as of January 1, 1996. The State Register also includes medical, dosimetric and sociological subregisters. The 'Medical subregister' provides data on the special purpose clinical examinations and medical care for suffering people. The 'Dosimetric subregister' provides data on the measured and reconstructed doses of irradiation. The 'Sociological subregister' is divided based on the selected groups forming categories of suffering people which are included in the State register. The Ukrainian Military Register, units of which are managed by the Ministry of Defense and the Ministry of Internal Affairs and 
Table 8 The structure of the State Register of persons who suffered from the Chernobyl catastrophe. ${ }^{4)}$ (persons, 01.01.1996)

\begin{tabular}{|c|c|c|c|c|c|}
\hline & Group A & Group B & Group C & Group D & \\
\hline & Liquidators & $\begin{array}{c}\text { Evacuees and } \\
\text { resettlers }\end{array}$ & $\begin{array}{c}\text { Residents in the } \\
\text { contaminated } \\
\text { areas }\end{array}$ & $\begin{array}{l}\text { Childıen born } \\
\text { with parents of } \\
\text { Group A-C }\end{array}$ & Total \\
\hline Adults & 184,672 & 53,866 & 161,611 & - & 400,149 \\
\hline Children & - & 8,845 & 27,907 & 37,194 & 73,946 \\
\hline Total & 184,672 & 62,711 & 189,518 & 37,194 & 474,095 \\
\hline
\end{tabular}

Security Service of Ukraine, is also a part of the State Register.

Organizational structure of the State Register has the following levels of management:

a) State level-the Ukrainian Centre of Medical Information Technologies and National Register of the Ministry of Health of Ukraine, respective special units of the Ministry of Defense and the Ministry of Internal Affairs and Security Service of Ukraine, special departments of scientific research institutes of the Academy of Medical Sciences and the National Academy of Sciences of Ukraine;

b) Region and city level-regional or city hospitals.

c) District level-district hospitals.

Basically, district hospitals are supposed to collect medical data within this medical scheme. In principle, there are instructions that provide for a certain basis for proper data collection. However, it is recognized by international medical scientific experts that a lack of knowledge about the actual mechanisms of data collection and the quality of basic epidemiological statistics, such as mortality and cancer incidence, are factors which limit the international standard of epidemiological investigations in Ukraine.

\section{FINAL REMARKS}

1. The system of Chernobyl Laws in Ukraine reflects more the good intentions of Ukrainian authorities to help the people who suffered from the Chernobyl catastrophe, than scientifically justified recommendations. Firstly (in 1991), it was expected that funds for implementation of the laws would come from the budget of the Soviet Union. After the break up of the Soviet Union, it was found that the laws were overloaded with social payments and compensation and became impracticable taking into account the state of economy of the independent Ukraine. The actual annual income to the Chernobyl fund is about $70-80 \%$ of what is prescribed by the laws for their implementation.

A number of changes and additions to the laws reflects the special attention to the Chernobyl problem by Verkhovna Rada deputies and the public in general. This is being exploited by politicians, with Chernobyl issues becoming a field of political struggle between pragmatists and populists. In this situation, radiological aspects of the problem were swept aside.

Radiological survey system in Ukraine provides necessary information on the annual doses to the population of each settlement on the contaminated territories. Despite the clearly observed reduction of doses on most territories, allocation of settlements to the categories of contaminated zones has not been reviewed since 1991. According to the monitoring data, the level of irradiation doses of about $50 \%$ of all settlements does not correspond to their present status (in relation to their zones).

What is very important in the present situation is to stop compulsory resettlement (senseless after 11 years have passed since the accident) and redirect resources to the reconstruction of people's lives on 
the contaminated territories. It is necessary to stop paying compensation for the production of radioactively contaminated food products and instead introduce a system of benefits to those who produce pure products on contaminated territories.

These elements of a new approach to the Chernobyl problem as well as many others are presented in the new "Concept of protection of population in connection with the Chernobyl catastrophe" elaborated together by MinChernobyl and NCRPU. This document was submitted to the Cabinet of Ministers and approved by it in autumn of 1997. It is expected that on approval of Verkhovna Rada it will become the new basis for reviewing the Chernobyl laws.

2. Laws and regulations of Ukraine on radiation protection are on the way to meeting international basic safety standards. There is no experience, however, in the world of dealing with the consequences (especially long-term ones) of such a wide-scale radiation catastrophe as Chernobyl. Taking into account that a certain part of the Ukrainian population has to live permanently on the radioactively contaminated territories, the contamination on this territories is not considered an accidental (people can not live permanently in accidental conditions), but rather an environmental factor like natural radioactivity. This provides a somewhat different approach to setting acceptable levels of radionuclides in foodstuffs and explains the differences in figures between AL-97 and international recommendations. ${ }^{5)}$

ACKNOWLEDGMENT: This study was supported by a research grant of the Toyota Foundation. The authors are grateful to Ms. Cynthia HEFFELFINGER for her help in preparation of the manuscript.

\section{References}

1) International basic safety standards for protection against ionizing radiation and for the safety of radiation sources.-Vienna: International Atomic Energy Agency, 1996.-(Safety Series, No 115. Safety Standards). STI/PUB/996.

2) MAtsko, V.P. and ImAnAKA, T; Legislation and research activity in Belarus about the radiological consequences of the Chernobyl accident: Historical review and present situation, Journal of Health Physics, 32(1), 81-96 (1997).

3) Ryabtsev, I.A. and Imanaka, T.; "Legislation and research activity in Russia about the radiological consequences of the Chernobyl accident," Journal of Health Physics, 32(2), 211-225 (1997).

4) Ten years after the accident at the Chernobyl NPP: National report of Ukraine, MinChernobyl, 1996 (in Russian).

5) Derived intervention levels for radionuclides in food. Guidelines for application after widespread radioactive contamination resulting from a major radiation accident. World Health Organization. Geneva, 1988.

\section{Appendix A. Short description of leading research organizations about the Chernobyl problems}

\section{A.1. Scientific Centre for Radiation Medicine of the Academy of Medical Sciences of Ukraine}

The Scientific Centre for Radiation Medicine (SCRM) is the leading scientific institute of the Academy of Medical Sciences of Ukraine and the Ministry of Health of Ukraine, which works on the medical problems of the Chernobyl accident.

The total number of personnel of the Center as of 01.01.1995 was 1,254 persons, including 236 scientists (30 doctors, 90 candidates).

The structure of SCRM comprises three institutes:

- Institute of Clinical Radiology with a clinic of 300 beds;

- Institute of Epidemiology and Prophylactics of X-ray Diseases;

- Institute of Experimental Radiology and outpatient clinic for radiation registration.

The SCRM performs basic and applied research.

The main trends of its research are:

- investigation and assessment of radiation and non-radiation factors of the Chernobyl accident, as well as of other sources of ionizing radiation which affect the health of people;

- investigation of the health status of the population which suffered from the Chernobyl accident 
and those of other categories which receive additional irradiation doses;

- scientific grounds and support of medical measures on the protection of the population from negative effects of the Chernobyl accident and other sources of radiation;

- scientific support and generalization of the data presented by the State Register about the persons who suffered from the Chernobyl accident;

- study of the mechanism of ionizing radiation effects and negative factors influencing human beings, development of prophylactics, diagnostics, treatment and rehabilitation methods.

Reconstruction of thyroid doses for 12 regions and the city of Kyiv due to the Chernobyl accident has been carried out at the Department of Dosimetry and Radiation Hygiene of SCRM (Dr.

I. KAIRO). Results for 7 regions and the city of Kyiv were approved by the Ministry of Health and presented to the Ukrainian government as Thyroid Dosimetric Passports. The Ministry of Emergencies (MEA) supports this work and is planning to provide such passports to the whole Ukrainian territory until the end of 1999.

Work on reconstruction of external and internal doses at an early stage after the accident is also being carried out at this Department (Drs. V. Repin, V. Chumak, V. Berkovsky, O. BONDARENKO) in cooperation with the staffs from other institutes. This Department is leaded by Prof.

I. LiKhTAREV.

\section{A.2. State Scientific Center of Environmental} Radiogeochemistry of NASU and MEA

The State Scientific Center of Environmental Radiogeochemistry (SSCER) was created in 1996 based on two departments of the Institute of Geochemistry, Mineralogy and Ore Forming: the Department of Environmental Radiogeochemistry and the Department of Metallogenesis.

The Center was created in order to improve the coordination and management of scientific research on the behavior of artificial and natural radionuclides and chemical substances in the environment, to create a data basis of scientific works on this subject, to prepare recommendations on restoration of the environment, including problems of decontamination and rehabilitation of the exclusion zone of the Chernobyl NPP and other territories subject to the harmful influence of technogenic and natural catastrophes; scientific supervision of the development of the uranium industry and radioactive waste treatment, including preservation, disposal and deposition in deep geological formations.

SSCER has the following 9 scientific sections:

- Section of nuclear geochemistry and cosmochemistry (Е. Sовотоvich),

- Section of radiogeochemistry of ecosystems (G. BondarenKo),

- Section of ecological geology (V. BUKHAREV);

- Section of geochemistry of technogenesis (B. GorLyTSKY),

- Section of cosmoecology and cosmic mineralogy (V. Semenenko),

- Section of problems of ecological safety (Ju. MELNYK),

- Section of metalogenesis and mineral resources (Eu. KULISH),

- Section of geology of uranium and attendant metals (V. Koval),

- Section of complex problems of uranium deposits (B. ZANKEVYCH).

Total number of staff members is 200 persons, including 72-scientific workers, among the last1 academician of NASU, 3 correspondent members of NASU, 15-doctors of science, 47- Ph. D candidates.

The main directions and subjects of investigations include:

- geochemical fundamentals of noosphere forming,

- technogenic-ecological safety and rehabilitation of contaminated territories,

- treatment, preservation, disposal and deposition (burial) of radioactive and toxic wastes,

- ecological assessment and forecasting of the environment status,

- complex problems of ecological safety and forecasting of emergencies.

\section{A.3. Chernobyl Scientific-Technical Center for International Research}

The Chernobyl Scientific-Technical Center for 
International Research (ChSCIR) was created in March 1996 based on the Scientific-Technical Center (STC) that existed within the structure of the Research-Industrial Association (RIA) "Pripyat" and the research infrastructure of Chernobyl Center for International Research (CheCIR). The last organization had up-to-date equipment for radioecological study and carried out associated investigations with CEC within the frame of ECP-JSP projects in 1993-1995.

ChSCIR is headed by the director, Prof. N. ARKHIPOV and includes 7 sections:

- Section of analysis and research work organization (A. MAKHNO),

- Section of study of radionuclides spreading (V. NADVORSKY),

- Section of radiology and recultivation (L. Loginova),

- Section of forest radioecology (M. KuCHMA),

- Section of radiobiology and medicine (M. Alesina),

- Section of international analytical research (V. LIBMAN),

- production-technical section (G. MYKHAILYUK), and special experimental farm (M. NovoPASHEN).

ChSCIR has 159 staff members, among them 80 graduate specialists, 4 doctors of science, $15 \mathrm{Ph}$. D candidates.

Directions of research work:

- elaboration and implementation of radioecological monitoring system of radioactively contaminated territories,

- complex investigations, analysis and forecast of space distribution and migration of radionuclides in the environment and food chains,

- study of radiogeochemical status of the exclusion zone on the basis of geochemical and hydrogeological observations,

- radiobiological and medical-biological consequences of the Chernobyl accident,

- study of the influence of radioactive contamination upon forest ecosystems and development of a special forestry system,

- elaboration, examination and implementation of countermeasures to reduce radionuclide trans- fer from soil to plant and through the food chain, and methods for rehabilitation of radioactively contaminated agricultural lands,

- study of the influence of microbiological agents upon transformation and migration of radionuclides and their compounds (including initial fallouts),

- elaboration and implementation of geographical information-modeling systems,

- forecast of ecological and radioecological status of the exclusion zones,

- provision of information about research work, elaboration of standardizing basic documents, elaboration of united informational data bank on scientific research works, standardizing technical documents, working materials of conferences, workshops etc.

ChSCIR has well-equipped laboratories and experimental field stations located at a distance of 3-15 km from ChNPP and is experienced in sampling of soil, water and biological objects. Its laboratories and vivariums, greenhouses and field stations are suited to carry out various radiobiological and radioecological investigations. Spectrometric and radiochemical laboratories, natural experimental fields, cooling pond of ChNPP with a special fish-breeding farm, vivariums for about 2 thousand laboratory rats and mice are also open to those who want to carry out radioecological and radiobiological studies there.

\section{Appendix B. List of interesting publications on Chernobyl by Ukrainian scientists}

1. Evtushenko, N. Yu., Kuzmenko, M.I., SIRENKO, L.A. et al.; "Hydroecological Consequences of the Chernobyl NPP Accident" (1992), Naukova Dumka, Kyiv (in Russian).

2. Romanenko, V.D., KuZMEnKo, M.I., Evtushenko, N. Yu. et al.; "Radioactive and Chemical Pollution of Dnieper River and Its Reservoirs after the Chernobyl NPP Accident" (1992), Naukova Dumka, Kyiv (in Russian).

3. Romodanov, A.P. ed.; "Post-Accidental Encephalopathy: Experimental Studies and Clinical Observations" (1993), Ukr SRI Neurosurgery (in Ukrainian). 
4. Serkiz, Ya.I., Pinchuk, V.G., Pinchuk, L.B. et al.; "Radiobiological Aspects of Chernobyl NPP Accident" (1992), Naukova Dumka, Kyiv (in Russian).

5. Frantsevych, L.I., Gaichenko, V.A., KryZhanovsky, V.I.; "Animals in Radioactive Zone" (1991), Naukova Dumka, Kyiv (in Russian).

6. "Accident at Chernobyl NPP: Radiation Monitoring, Clinical Problems, SocialPsychological Aspects, Demographic Situation, Low Doses of Ionizing Radiation" (1992), Inform. Bull., Kyiv (in Russian).

7. "Medical Consequences of Chernobyl NPP Accident" (1991), Inform. Bull., Kyiv (in Russian).

8. Health Ministry of UkrSSR, SCRM AMS USSR; "Problems of Radiation Medicine", Repub. Cooper. Collect., Issue 1 (1988), Kyiv (in Russian).

9. Health Ministry of UkrSSR, SCRM AMS USSR; "Problems of Radiation Medicine", Repub. Cooper. Collect. Issue 2 (1989), Kyiv (in Russian).

10. "Actual Problems of Liquidation of Medical Consequences of Chernobyl NPP Accident: Collection" (1992), Kyiv (in Russian).

11. Kuchin, O.V., KhalimonchuK, V.A.; Neutron-Physical and Thermo-Physical Investigations on Unit 4 of ChNPP, Rep. NAS Ukraine (Doklady Akademii Nauk Ukraunskoi SSR), 1993, No. 1. p. 140. (in Russian)

12. "Chernobyl Accident: Events, Facts, Figures. April 1986-March 1990" (1990), Civil Defense Headquarters of Ukrainian SSR, Kyiv (in Russian).

13. "Radiation Aspects of the Chernobyl Accident: Collection" Part 2 (1989), Kyiv (in Russian).

14. Dolin, V.V., Bondarenko, G.N., Soвotovich, E.V.; Diffussional Mechanism of Migration of ${ }^{137} \mathrm{Cs}$ and ${ }^{90} \mathrm{Sr}$ of ChNPP Fuel Fall-outs, Doklady Akademii Nauk Ukraunskoi SSR Seria. B, 1992 No. 12 p. 6-10 (in Russian).

15. Prister, B.S. et al.; Efficacy of Measures Aimed at Decreasing Contamination of Farm Produce in Regions Contaminated as a Result of the Chernobyl NPP Accident, Doklady
Akademii Nauk Ukraunskoi SSR, 1992 No. 1 p. 157-161 (in Russian).

16. Soвotovich, E.V., Olkhoviк, Yu.A., Koromyslichenko, T.I., SOKOLIK, G.A.; Comparative Study of Migration Ability of Radionuclides in Bottom Sediments of WaterBodies in Near Zone of ChNPP, Doklady Akademii Nauk Ukraunskoi SSR, 1990 No. 8, p. 12-18 (in Russian).

17. Sobotovich, E.V., Chebanenko, S.I.; Isotopic Composition of Uranium in Soils of Near Zone of ChNPP, Doklady Akademii Nauk SSSR, 1990 No. 4, p. 885-888 (in Russian).

18. Pinchuk, L.B., Rodionova, N.K., Serkiz, Ya.I.; Changes of Hematological Indices, Frequency of Neoplasm Revealing and Lifetime of Experimental Animals during 6 Years after Chernobyl NPP Accident, Doklady Akademii Nauk Ukraunskoi SSR, 1993 No. 1, p. 148-153 (in Russian).

19. Sobotovich, E.V., Shestopalov, V.M., Pushrarev, A.V. et al.; Principals of Landscape-Geochemical and Radioecological Mapping of Territory, Contaminated with Thechnogenical Radionuclides, Doklady Akademii Nauk Ukraunskoi SSR, 1993. No. 1, p. 177-181 (in Russian).

20. Sobotovich, E.V., Bondarenko, G.M. et al.; "Radiogeochemistry in the Chernobyl NPP Influenced Zone" (1992), Naukova dumka, Kyiv, (in Russian).

21. Nyagu, A.I.; Psycho-neurological and Psychological Aspects of the Consequences of Chernobyl NPP Accident, Vestnik Akademii Meditsynskikh Nauk USSR, 1991 No. 11, p. 3132 (in Russian).

22. NyAGU, A.I.; Social-Psychological and Psycho-neurological Aspects of the Consequences of the Chernobyl NPP Accident, Vestnik Akademii Meditsynskikh Nauk USSR, 1991 No. 11, p. 21-25 (in Russian).

23. Kindzelsky, L.P., Klymenko, V.I., LYSETSKY, V.A. et al.; Some Questions of Diagnostics of Diseases and of Those Who Suffered during the Chernobyl NPP Accident, Vrachebnoe Delo, 1991 No. 3, p. 3-6 (in Russian).

24. National Academy of Sciences of Ukraine; 
"Chernobyl Catastrophe." Naukova Dumka, Kyiv, 1995 (in Russian), 1996 (in Ukrainian), 1997 (in English).

25. Assimakopoulos, P., Loannides, K.G., Karamanis, D., Lagoyannis, D., Pakou, A.A., Koutsotolis, K., Nikolaou, E., Arkhipov, A., Arkhipov, N., Gaschak, S., Kurman, A., Chizhensky, I.; Ratios of Transfer Coefficients for Radiocesium Transport in Ruminants, Health Physics, Vol. 69, p. 410-414 (1995).

26. Baker, R.J., Hamilton, M.J., VAN, R.A., Bussche, D., Wiggins, L.E., Sugg, D.W., SMith, M.H., Lomakin, M.D., Gaschak, S.P., Buntova, E.G., ARKhIPOV, N.P., Rudenskaya, G.A., Chesser, R.K.; Small Mammals from the Most Radioactive Sites near the Chernobyl Nuclear Plant, J. Mammal, Vol. 77, p. 155-170 (1996).

27. Bugai, D.A., Waters, R.D., Dzhepo, S.P., SkAL'SKIJ, A.S.; Risk from Radionuclide Migration to Groundwater in the Chernobyl 30-km Zone, Health Physics, Vol. 71, p. 9-18 (1996).

28. Voitsekhovitch, O., Prister, B., Nasvit, O., Los, I., Berkovski, V.; Present Concept on Current Water Protection and Remediation Activities for the Areas Contaminated by the 1986 Chernobyl Accident, ibid., p. 19-28.

29. Pilinskaya, M.; The Results of Selective Cytogenetic Monitoring of Chernobyl Accident Victims in the Ukraine, ibid., p. 29-33.

30. Berkoviski, V., Ratia, G., Nasvit, O.; Internal Doses to Ukrainian Populations Using Dnieper River Water, ibid., p. 37-44.

31. "Ten Years after the Accident at the Chernobyl NPP: National Report of Ukraine" (1996), Minchornobyl, Infotsentr Chornobyl, Kyiv, (in Russian and Ukrainian).

32. "Health Indices of People Who Suffered from the Accident at Chernobyl Nuclear Power Plant (1987-1995)," Statistical Handbook, Minchornobyl of Ukraine, Health Ministry of Ukraine, Center for Medical Statistics. Kyiv, 1996 (in Ukrainian).

33. Bobylyova, O.A.; Assessment of Medical Consequences of the Chernobyl NPP Accident for Six-year Period in Ukraine, Dopovidi Akademiyi Nauk Ukrayiny, 1993 No. 1 (in Ukrainian).

34. "Problems of Agricultural Radiology," Collection 1992, Kyiv (in Russian).

35. "Problems of Agricultural Radiology," Collection. Issue 3, 1993, Kyiv (in Russian).

36. DavydchuK, V.S., Zarudnaya, R.F., MiKhELI, S.V.; "Landscapes of the Chernobyl Zone and Their Assessment by the Conditions of Radionuclides Migration" (1994), Naukova Dumka, Kyiv (in Ukrainian).

37. RudNEv, M.I. ed.; "Influence of Low Doses of Ionizing Radiation and Other Factors of the Environment upon the Organism" (1994), Naukova Dumka, Kyiv (in Russian).

38. Prister, B.S., Loshchilov, N.A., Nemets, O. F., Poyarkov, V.A. et al.; "Fundamentals of Agricultural Radiology" (1991), Urozhai, Kyiv (in Russian).

39. Likhtarev, I., Chumak, V., Repin, V.; Retrospective Reconstruction of Individual and Collective External Gamma Doses of Population Evacuated after the Chernobyl Accident, Health Physics, Vol. 66, p. 643-652 (1994).

40. Likhtarev, I. et al.; Results of Large Scale Thyroid Dose Reconstruction in Ukraine, Proceedings of the First International Conference. Minsk, Belarus, 18 to 22 March 1996. p. 1021-1034. EUR 16544 EN.

41. Prisyazhniuk, A., Gristchenko, V., ZAKordonets, V. et al.; The Time Trends of Cancer Incidence in the Most Contaminated Regions of the Ukraine before and after the Chernobyl Accident, Radiat. Environ. Biophys., Vol. 34, p. 3-6 (1995).

42. Gulko, G.M. et al.; Estimation of ${ }^{131}$ I Thyroid Doses for the Evacuees from Pripjat, Radiat. Environ. Biophys., Vol. 35, p. 81-87 (1996).

43. "Chernobyl Tragedy: Documents and Materials" (1996), Naukova Dumka, Kyiv (in Ukrainian).

44. "Chernobyl: Problems of Public Health: Collection of Documents, Parts 1 \& 2," (1995), Institute of History of Ukraine, Kyiv (in Ukrainian). 